\title{
EDUCAÇÃO DE JOVENS E ADULTOS EM PRIVAÇÃO DE LIBERDADE - ESCUTANDO VOZES SILENCIADAS
}

\author{
YOUNG AND ADULT EDUCATION WITH FREEDOM PRIVATION - LISTENING TO SILENCED VOICES
}

EDUCACIÓN DE JÓVENES Y ADULTOS EN PRIVACIÓN DE LIBERTAD - ESCUCHANDO VOCES SILENCIADOS

MADERS, Sandra 1

BARCELOS, Valdo²

\begin{abstract}
RESUMO
Este texto tem como temática central a Educação de Jovens e Adultos (EJA) em situação de Privação de Liberdade. No artigo procedemos a uma reflexão sobre a experiência de educandos de jovens e adultos (alfabetização) oriundos de três instituições prisionais brasileiras. Os apenados se encontram no Regime Semi-aberto de cumprimento de pena. Foram selecionados três diálogos/relatos entre apenados e professores. Percebeu-se que ainda persiste uma visão preconceituosa de parte dos professores em relação a esses educandos; essa visão se estende, inclusive, à relevância e necessidade dessa modalidade de educação, bem como reconhecer a formação de professores como uma estratégia crítica, autocrítica e ressignificação de preconceitos.
\end{abstract}

Palavras-chave: Educação de Jovens e Adultos. Privação de Liberdade. Vozes silenciadas.

\section{ABSTRACT}

This text has as its main topic the Young and Adult Education (EJA) in Freedom Privation situation. In this article we engage in a reflection about the experience of education of young people and adults (literacy) that come from three Brazilian prison institutions. The convicted find themselves inserted in the Semi-Open Conditions of prison penalty. Three dialogues between the convicted and teachers were selected. It was noticed that a prejudiced point of view still persists coming from the teachers about these learners; this vision extends the relevance and the need of this type of education, as well as to recognize the formation of teachers as a critical strategy, self-criticism and resignification of prejudices.

Keywords: Young and Adult Education. Freedom Privation. Silenced voices.

\section{RESUMEN}

Este texto tiene como temática central la Educación de Jóvenes y Adultos (EJA) en situación de Privación de Libertad. En el artículo procedimos a una reflexión sobre la experiencia de educados de jóvenes y adultos (alfabetización) oriundos de tres instituciones penitentes brasileñas. Los apenados se encuentran en el Régimen Semi-abierto de cumplimiento de pena. Se seleccionaron tres diálogos entre apenados y profesores. Se percibió que aún persiste una visión preconcebida de parte de los profesores en relación a esos educandos; esta visión se extiende, inclusive, la relevancia y necesidad de esa modalidad de educación, así como reconocer la formación de profesores como una estrategia crítica, autocrítica y resignificación de prejuicios. Palabras clave: Educación de Jóvenes y Adultos. Privación de Libertad. Voces Silenciadas.

\footnotetext{
1 Universidade Federal do Pampa - UNIPAMPA - Bagé - Rio Grande do Sul - Brasil

2 Universidade Federal de Santa Maria - UFSM - Santa Maria - Rio Grande do Sul - Brasil
} 


\section{UM POUCO DE HISTÓRIA... PARA INÍCIO DE CONVERSA}

"La realidad no és así, esta así."

(Paulo Freire, 2003)

Nas primeiras décadas do Século $X X$ toma corpo no Brasil a ideia de que existia uma relação determinante entre algumas características físicas, biológicas e psíquicas que poderiam levar algumas pessoas a praticar a criminalidade. Tal doutrina teve a denominação oficial de escola constitucionalista.

As ideias dessa doutrina eram, inclusive, demonstradas por meio de exames morfológicos e de análises bioquímicas dos ditos delinquentes e criminosos. Ou seja: os defensores dessas ideias jactavam-se de que as mesmas tinham caráter científico. Um dos pioneiros e defensor entusiasta dessa ideia foi o médico Raymundo Nina Rodrigues (1862-1906). Esse médico, inclusive, realizou estudos e pesquisas anatômicas em corpos de "delinquentes" com o intento de comprovar, cientificamente, sua doutrina. Vale ressaltar que essas ideias tiveram importante repercussão no pensamento de significativas parcelas da população brasileira de então. Ou seja: não ficaram restritas aos setores "intelectualizados" da elite nacional e do mundo da ciência. Serviram como argumento para justificar uma série de arbitrariedades e de discriminações. Os setores desfavorecidos economicamente, os de origem africana e indígenas foram os mais atingidos pelas consequências negativas dessas doutrinas de caráter discriminatório e racista.

Com o processo de urbanização da sociedade brasileira e o surgimento de cidades com milhares de habitantes, os índices de violências cometidos nos espaços públicos sofrem um crescente considerável. As pessoas que eram detidas cometendo delitos eram levadas para delegacias e pontos de detenção. Esses locais, antes de caráter provisório, passaram a ser permanentes e suas condições, do ponto da qualidade de vida dos detidos, tornaram-se insustentáveis e insuficientes para abrigar número tão grande de pessoas. Surgem então as instituições prisionais sob a responsabilidade do Estado Brasileiro. Não paira dúvida sobre o fato de que desde a antiguidade da história humana existem os mecanismos de punição nas sociedades. Essas punições eram, via de regra, diretas, ou seja: os considerados criminosos eram torturados, executados, enfim, sofriam punições imediatas como forma de purgar seus crimes.

No entanto, a decisão de punir as pessoas infratoras com o encarceramento - privação da liberdade de ir e vir - só começa a ganhar efetividade em torno do século XVIII. Ou seja, no que se convencionou denominar de Idade Moderna da civilização ocidental. Com isso começa a viger a ideia de que os infratores e criminosos deveriam expiar suas culpas aos olhos da sociedade que, em última instância, era quem deveria ser protegida dos criminosos. Ao serem retirados do convívio social e encarcerados os criminosos estariam impedidos de continuar agredindo os demais cidadãos. 
As instituições prisionais como as que temos hoje, com o sentido de punir, reeducar os infratores e reinseri-los na sociedade, se inicia no século XVIII e início do século XIX. Certamente que essas mudanças não se deram sem sobressaltos. A ideia de que a tendência para a criminalidade estava relacionada com fatores biológicos e genéticos permaneceu por um bom tempo nas escolas de direito e de medicina brasileiras. Um exemplo disto é a doutrina da escola positivista de criminologia surgida na Itália com a antropologia criminal de Cesare Lombroso (1835-1909) e que encontrou abrigo nos adeptos da doutrina positivista no início do período republicano brasileiro.

O que se pode constatar é que a ideia de instituições prisionais, como local de ressocialização, com raras exceções, não foram bem sucedidas no Brasil, como de resto em toda a América Latina. As causas são motivo de intensos debates nos diferentes segmentos da sociedade. Contudo, pode-se dizer que alguns consensos se formaram quanto às origens desse fracasso, tais como: a falta de investimento financeiro de parte dos poderes públicos; uma imensa rede de aparatos burocráticos nos diferentes níveis de administração pública; carência de pessoal com formação adequada para trabalhar nas instituições prisionais; a instabilidade das políticas públicas e de gestão que acabam sendo mudadas conforme as orientações ideológicas dos governantes que assumem o poder; altos índices de corrupção de agentes públicos e de organizações privadas que acabam interferindo na gestão dos recursos financeiros e, não se pode esquecer o forte traço autoritário e discriminatório presente na sociedade brasileira. Não podemos desconsiderar também, o fato, por exemplo, de o Brasil ter sido o último país do mundo ocidental a abolir, do ponto de vista oficial e legal, a escravidão dos homens negros e das mulheres negras sequestrados no continente africano e para o Brasil trazidos como mercadoria (escravos) para trabalhar nas lavouras dos grandes latifundiários. Seria muita ingenuidade imaginar que isso não tenha reflexos até os dias de hoje sobre a forma como são tratadas algumas pessoas pertencentes às camadas mais desfavorecidas economicamente na sociedade brasileira. Não por acaso é significativamente maior a percentagem de pessoas pobres, negras e de baixa escolaridade nas instituições prisionais no Brasil.

Ainda é possível escutar-se frases preconceituosas e autoritárias como "bandido bom é bandido morto"; que a sociedade além de sofrer a violência dos bandidos ainda tem que thes proporcionar "cama, comida e banho de sol". Essas e outras expressões que se tornaram parte do senso comum em certas rodas de conversas refletem um total desprezo pela dignidade dos seres humanos e um sentimento de superioridade que algumas pessoas ainda preservam. $O$ artista plástico Vick Muniz sintetiza essa cultura de dominação e de arrogância dizendo que após viajar e morar em vários países do mundo, ainda se surpreende quando está no Brasil - seu país de origem - e percebe que aqui ainda existem pessoas que acreditam, sinceramente, que são melhores que as outras ${ }^{3}$.

A situação da educação nas prisões brasileiras, com certeza, é afetada por concepções e compreensões desse tipo. No Relatório Nacional para o Direito Humano à Educação nas Prisões Brasileiras (2009) fica muito explícita a forma precária como a Educação de Jovens e Adultos é vista e

\footnotetext{
${ }^{3}$ Diálogo no filme documentário O Lixo Extraordinário (2010).
} 
tratada. Nas Diretrizes Curriculares Nacionais para a Educação Básica - Diversidade e Inclusão (2013 e 2018) no capítulo destinado à Educação de Jovens e Adultos, em situação de privação de liberdade em estabelecimentos penais brasileiros são assim sintetizadas essa realidade:

- a educação para pessoas encarceradas ainda é vista como um "privilégio" pelo sistema prisional;

- a educação ainda é algo estranho ao sistema prisional. Muitos professores e professoras afirmam sentir a unidade prisional como uma ambiente hostil ao trabalho educacional;

- a educação se constitui, muitas vezes, em "moeda de troca" entre, de um lado, gestores e agentes;

- prisionais e, do outro, encarcerados, visando a manutenção da ordem disciplinar;

- há um conflito cotidiano entre a garantia do direito à educação e o modelo vigente de prisão, marcado pela superlotação, por violações múltiplas e cotidianas de direitos e pelo superdimensionamento da segurança e de medidas disciplinares.

Quanto ao atendimento nas unidades:

\begin{abstract}
é descontínuo e atropelado pelas dinâmicas e lógicas da segurança. $\mathrm{O}$ atendimento educacional; é interrompido quando circulam boatos sobre a possibilidade de motins; na ocasião de revistas. (blitz); como castigo ao conjunto dos presos e das presas que integram uma unidade na qual ocorreu uma rebelião, ficando à mercê do entendimento e da boa vontade de direções e agentes penitenciários; é muito inferior à demanda pelo acesso à educação, geralmente atingindo de $10 \%$ a $20 \%$ da população encarcerada nas unidades pesquisadas. As visitas às unidades e os depoimentos coletados apontam a existência de listas de espera extensas e de um grande interesse pelo acesso à educação por parte das pessoas encarceradas; quando existente, em sua maior parte sofre de graves problemas de qualidade apresentando jornadas reduzidas, falta de projeto pedagógico, materiais e infraestrutura inadequados e falta de profissionais de educação capazes de responder às necessidades educacionais dos encarcerados. (CARREIRA, 2009, p.2).
\end{abstract}

\title{
EDUCAÇÃO DE JOVENS E ADULTOS HOJE
}

A educação deve ser um ato coletivo, solidário - um ato de amor... Educar é uma tarefa de trocas entre pessoas e não pode ser nunca feita por um sujeito... Não pode ser também o resultado do despejo de quem supõe que possui todo o saber, sobre aquele que, foi obrigado a pensar que não possui nenhum. (BRANDÃO, 1988, p. 22).

A situação da Educação de Jovens e Adultos no Brasil continua em uma condição dramática. Estamos como que pouco mais que estagnados quando a avaliação educacional se refere à Educação de Jovens e Adultos. Os indicadores da Pesquisa Nacional por Amostragem de domicílios (PNAD) do 
ano de 2017/IBGE revelaram, tristemente, a existência de 14 milhões de analfabetos no Brasil. Falamos tristemente, mas, a expressão mais adequada talvez fosse vergonhosamente. A razão é simples: este número absoluto é quase o mesmo do ano de 1960 (15 milhões). Sem dúvida que a população brasileira aumentou e muito. Hoje somos cerca de duzentos milhões de pessoas. No entanto, não estamos tratando simplesmente de cifras, de números. Quando tratamos de educação e de Educação de Jovens e Adultos, estamos tratando de pessoas que não tiveram acesso a boniteza (FREIRE, 2000) de aprender a ler e a escrever.

Outra questão que merece atenção é o fato de que a educação brasileira, em termos gerais, melhorou seus indicadores nas últimas décadas. Então, o que está acontecendo com a Educação de Jovens e Adultos, em especial com a alfabetização? O alerta feito, sistematicamente, por Gadotti sobre esse cenário merece atenção. Para ele "A taxa de analfabetismo no Brasil está praticamente estagnada. A nação deveria ficar chocada diante desses dados que revelam flagrante desrespeito aos direitos humanos" (GADOTTI, 2009, p. 05). Esta reflexão feita por Gadotti, que coloca a Educação de Jovens e Adultos ao lado de outras questões de Direitos Humanos, é uma excelente proposição no sentido de mostrar a responsabilidade dos diferentes níveis de governo (Federal, Estadual e Municipal), como, também, chama à responsabilidade todos nós que fizemos parte desta sociedade injusta e excludente.

Existem muitas vergonhas a serem enfrentadas por todos (as) nós brasileiros (as), contudo, esta, da exclusão da escola de um número tão grande de homens e mulheres oriundos dos setores populares não pode mais ser adiada, sob pena de aceitarmos como "natural" a negação da cidadania a este imenso contingente de brasileiros (as).

É neste sentido que pensamos a Educação de Jovens e Adultos não como um fim. Não como um ponto de chegada, mas, sim, como um primeiro passo, como um ponto de partida para a construção e/ou para a ampliação da cidadania de homens e de mulheres que se encontram à margem do processo de participação nas riquezas e nas oportunidades de trabalho, lazer, saúde, etc. A Educação de Jovens e Adultos pode se constituir em uma das portas que possibilitarão, a uma significativa parcela de brasileiros e brasileiras, que não puderam frequentar a escola na idade adequada, o acesso aos diferentes bens e serviços produzidos em sociedade. Nunca é demais lembrar que mesmo não tendo a escolarização necessária e aconselhada, para a vida no mundo contemporâneo, esses homens e mulheres participam, ativamente, com seu trabalho, da produção da riqueza deste país e deste mundo. Uma riqueza que, via de regra, Ihes é negada sua participação.

Não por mero acaso o direito a educação é referendado, no Artigo 26 da Declaração dos Direitos Humanos, promulgada no ano de 1948, como um direito fundamental da pessoa. Ter assegurado o direito à educação é uma condição necessária para a garantia do respeito e da manutenção da liberdade de qualquer pessoa no exercício pleno de sua cidadania. 
Ao comentar as proposições da V CONFITEA (UNESCO, 19974) na sua Declaração de Hamburgo, Gadotti (2009) destaca aquelas que consideram de grande relevância, quais sejam: a) reconhecer o papel indispensável do educador bem formado; b) reconhecer e reafirmar a diversidade de experiências; c) assumir o caráter público da EJA; d) ter um enfoque intercultural e transversal; e) a importância da EJA para a cidadania, o trabalho e a renda numa era de desemprego crescente; f) o reconhecimento da importância da articulação de ações locais; g) reconceituar a EJA como um processo permanente de aprendizagem; h) reafirmar a responsabilidade inegável do Estado diante da EJA; i) fortalecer a sociedade civil; j) reconhecer a EJA como uma modalidade da educação básica; k) resgatar a tradição de luta política da EJA pela democracia e pela justiça social.

Estas proposições da V CONFITEA, selecionadas por Gadotti, dão uma dimensão da importância e da complexidade exigida para o trabalho com a Educação de Jovens e Adultos.

Assim sendo, não há como tergiversar: o acesso à Educação Básica não é uma mera condição suficiente para a vida em sociedade, ela é uma condição necessária para a busca e garantia ao direito da educação continuada, permanente ou uma educação para toda a vida se assim a pessoa o desejar. Para a pesquisadora da Educação de Jovens e Adultos Jane Paiva, é fundamental a participação ativa e organizadora do Estado na Educação de Jovens e Adultos por meio de implementação de Políticas Públicas condizentes com os cenários locais. Para essa autora,

\begin{abstract}
Não há como negar o potente papel indutor do Estado no fazer das políticas, mesmo quando tímidas, nem como dispensar o Estado da responsabilidade com a EJA. O jogo de forças entre níveis e modalidades - todos com recursos escassos -; entre público e privado; entre modalidade presencial e a distância põe-se desfavoravelmente contra a EJA. O imaginário social invisibiliza os não alfabetizados/não escolarizados, com o concurso dos meios de comunicação, elegendo crianças e adolescentes como prioridade, e absolvendo o Estado pelo não cumprimento de um dever, por considerar cada sujeito interditado do direito como culpado pela própria condição. (PAIVA, 2006, p. 529).
\end{abstract}

Ao compreendermos a Educação de Jovens e Adultos em geral, e a Educação de Jovens e Adultos em situação de Privação de Liberdade em especial, com esta perspectiva política, cultural e de condição necessária para a justiça social, estaremos agregando a ela um caráter de promotora e facilitadora do processo de ressocialização e do acesso aos diferentes bens sociais, em especial, a um trabalho digno. Aliado a isso, amplia-se a possibilidade de compreensão, por parte dos (as) educandos e educandas da Educação de Jovens e Adultos, dos conteúdos e das proposições científicas que são inerentes às disciplinas nos diferentes níveis do processo educativo na Educação Básica.

Ao atribuirmos à Educação de Jovens e Adultos este estatuto de importância, a colocamos ao lado e em diálogo com outros temas dos direitos da pessoa a uma vida digna e justa. São temas como: ecologia, emprego, saúde, acesso aos bens culturais, direito a moradia digna, ao transporte de

\footnotetext{
4 V CONFITEA - Conferência Internacional de Educação de Jovens e Adultos. Esta Conferência teve a participação de 130 países e mais de 1500 inscritos. Além da Carta de Hamburgo a conferência declarou 2000/2010 a Década Paulo Freire da Educação de Jovens e Adultos.
} 
qualidade, a relações de interculturalidade, enfim, a educação tomada como um Direito Humano fundamental - não esqueçamos que estamos em pleno terceiro milênio.

Ao escrever sobre os Direitos Humanos e o papel da educação o escritor Antonio Candido (1918-2017) faz uma reflexão que nos provoca a pensar sobre a importância de atentarmos para o papel cidadão que pode ser ampliado com o acesso a leitura de um texto. $O$ autor evoca em seu texto clássico de 1970, intitulado Literatura e Subdesenvolvimento o Artigo 26 da Declaração dos Direitos Humanos como forma de exigir do Estado seu compromisso com a educação das pessoas. Vejamos o que prescreve o Artigo XXVI da Constituição da República do Brasil:

Toda pessoa tem o direito de participar livremente da vida cultural da comunidade, de fruir as artes e de participar do processo científico e de seus benefícios. Toda pessoa tem direito à proteção dos interesses morais e materiais decorrentes de qualquer produção científica, literária ou artística da qual seja autor. (Declaração Universal dos Direitos Humanos 1948 - Artigo XXVI).

A sociedade brasileira e suas elites acumularam, historicamente, imensas dívidas com amplas parcelas de sua população. Contudo, uma delas se faz inaceitável: a negação a milhares, a milhões de homens e de mulheres o direito básico a aprender a ler e a escrever. Uma das maneiras de resistir a esse processo de exclusão, orientado por uma visão de dominação patriarcal (MATURANA \& ZOLLER, 2004, p. 189), é buscar escutar as vozes, justo, dessas pessoas que foram, e são, alijados do convívio social pelos mais diferentes motivos. Referimo-nos ao enorme contingente de brasileiros que se encontram nas instituições prisionais e que não puderam completar ou mesmo iniciar seus estudos básicos.

\section{EDUCAÇÃO DE JOVENS E ADULTOS EM PRIVAÇÃO DE LIBERDADE - ESCUTANDO SILÊNCIOS}

“... sou da turma dos que não sabem nada... sou da turma dos burros...".

(Aluno de EJA-Alfabetização)

Para o educador e cidadão do mundo Paulo Freire (1921-1997) se constitui em grave equívoco buscar separar os processos educativos escolares dos processos de vida de educando e educandas. Para Freire, educandos e educandas se envolvem nos processos de aprendizagem, com mais interesse e naturalidade, se esses processos lhes forem oferecidos por meio de "Palavras pertencentes à sua experiência existencial, palavras grávidas de mundo. Palavras e temas" (FREIRE, 2003, p.25). Uma das maneiras de fazer essa aproximação é, justamente, diminuindo a distância entre o saber popular e o conhecimento dito científico. O educador popular Carlos Rodrigues Brandão, ao refletir 
sobre o cenário educacional brasileiro faz um alerta que considero importante no que diz respeito a buscarmos uma real aproximação entre o dito senso comum e o conhecimento científico. Para esse educador, vivemos um momento de proliferação vertiginosa de informações que precisam passar pelo processo de reflexão, particularmente, por parte de professores (as) e educadores de maneira geral, e, em particular, na educação de jovens e adultos. Para Brandão,

\begin{abstract}
Há um exagero de experiências por todo mundo, uma sobra de investigações a cada ano, algumas boas e úteis por muito tempo, e outras que afortunadamente envelhecem depressa. Há propostas de psicologias de pedagogias que sugerem "o que fazer com elas". Isto é necessário e quase sempre os estudos e as propostas são bem-vindos, mas a velocidade com que surgem $e$ se repetem chega a ser assustadora. "Menos para quem abriu mão de ler os livros com ideias inteiras e se contenta com resumos, resenhas e artigos de sete páginas nas viagens da internet." (BRANDÃO, 2002, p.192)
\end{abstract}

Com essa orientação será possível avançarmos no processo educativo em geral e, em particular de jovens e adultos. A alfabetização de adultos requer um cuidado especial particularmente quando se busca a inserção e/ou reinserção de pessoas privadas de liberdade ou que estejam por muitos anos afastadas dos ambientes e processos de educação escolar. Ler palavras e ler os espaços vividos são duas leituras inseparáveis. Freire debateu-se por isso durante toda sua vida de educador. Nas suas palavras,

\footnotetext{
A leitura do mundo e a leitura da palavra estão dinamicamente juntas. O comando da leitura e da escrita se dá a partir de palavras e de temas significativos à experiência comum dos alfabetizandos e não de palavras e de temas apenas ligados à experiência do educador. (FREIRE, 1982, p. 57).
}

É com essa compreensão sobre o vivido, sobre a experiência, defendida por Freire e Brandão, como fundamental para o processo de aprendizagem, que as práticas pedagógicas e as alternativas curriculares, na Educação de Jovens e Adultos, podem começar a romper com a tradicional rotina escolar onde alguns, que tudo sabem, ensinam conhecimentos e técnicas para outros que mais memorizam que aprendem. A epígrafe com a qual iniciamos esta sessão é emblemática sobre os prejuízos causados por uma visão de educação "Bancária" (FREIRE, 1970, p. 32) e que coloca educadores (as) e educandos (as) em posições de superioridade e inferioridade.

Nessa ideia de experiência apresentada por Freire, o real não é algo a ser trazido por alguém para ser aprendido pelo outro por meio de uma mera repetição mecanicamente memorizada. Não. $\mathrm{O}$ real é uma construção que se dá a partir da leitura de mundo que cada um faz em seu processo de vida. Não devemos nos esquecer de que as crianças e os adultos, ao se envolverem nos processos educativos o fazem através de palavras pertencentes a sua história cultural, a sua experiência de vida. Como ensinava Paulo Freire (2003, p. 35) “A realidade não é assim, está assim”.

Como forma de exemplificar a necessidade de aproximação entre os diferentes campos e formas de conhecimento, apresentamos, a seguir, três relatos muito significativos de colegas professoras de Educação de Jovens e Adultos. O relato faz parte de uma pesquisa com formação de 
professores (as) em exercício na Educação de Jovens e Adultos. Este trabalho resulta de um conjunto de pesquisas junto a professores (as) em atuação na EJA nos últimos 12 anos. A ênfase foi dada para as narrativas destes professores (as) no sentido de promover uma aproximação com suas trajetórias pessoais e profissionais para, a partir destas, buscar reflexões sobre suas práticas pedagógicas de atuação docente. Essas pesquisas e relatos realizados no município de Santa Maria/RS estão por extenso nos livros:

- Educação de Jovens e Adultos: Currículo e Práticas Pedagógicas (2012 3ª ed.)

- Formação de Professores para Educação de Jovens e Adultos (Sendo resultado de cinco anos de trabalho com adultos, alfabetizandos, com educadores envolvidos com a educação de jovens e adultos, e com a alfabetização em particular) (2014).

- Políticas e Práticas na Educação de Jovens e Adultos (2015)

A professora em questão era diretora nos turnos da manhã e da noite. Neste último, era diretora e coordenadora pedagógica da Educação de Jovens e Adultos. O referido educando havia conseguido progressão de pena em função de ter bom comportamento e ter conseguido matrícula em uma escola onde estava se alfabetizando. Vamos à narrativa:

Quando uma colega diretora de outra escola me telefonou, dizendo que eu me preparasse para receber em minha escola, no dia seguinte à noite, um "presidiário bandido" que estava em regime aberto, entrei em pânico... Fiquei imaginando como eu faria... Como deveria me comportar na conversa que ia ter com ele na noite seguinte quando o referido aluno que cursava Educação de Jovens e Adultos $(E J A)$ - alfabetização - me procurasse na escola com a sua transferência em mãos...era a primeira vez que eu ia ter na minha escola um bandido estudando...minha escola era uma escola muito tranquila...tinha cerca de quatrocentos estudantes e uns trinta e cinco professores...todo mundo se entendendo bem...sem grandes conflitos.. sem brigas....os alunos, mesmo sendo gente pobre, eram pacíficos, ordeiros, enfim, tudo gente de bem...a maioria trabalhador, gente honesta... Fui pra casa e não tive sossego todo o final de semana... Nem dormia direito e quando dormia tinha pesadelos... Sonhava que o presidiário bandido era um negro enorme, musculoso, usando uma camisa de física sem manga, tinha o corpo cheio de tatuagens... Era careca e tinha várias cicatrizes... Umas horríveis no rosto. Na boca quase não tinha dentes...eu via, ele, em pé aos pés da cama me olhando com um jeito de dar medo....foram noites terríveis aquelas...acho que as piores que já vivi... 
Esta narrativa é de uma riqueza simbólica difícil de descrever e analisar. Contudo, algumas questões clamam por reflexão, como, por exemplo:

(1) quem disse para a colega professora e diretora da escola que o aluno transferido para "sua" escola era um homem negro?;

(2) quem deu a essa colega professora uma descrição física tão detalhada do mesmo?;

(3) como ela chegou a tal riqueza de detalhes sobre o aluno sem nem mesmo ter falado com ele por telefone? Ela nunca o tinha visto antes;

(4) de onde vem tanta certeza de que o presidiário era um homem negro e que era realmente um "bandido"?;

(5) o que significa para a colega professora uma escola de alunos ordeiros, pacíficos?;

(6) e "gente de bem" o que será que ela queria exatamente dizer com esta expressão?

Continuando a conversa com a professora (no intervalo do curso) ela foi além do relato. Contou-nos que tão logo recebeu o telefonema de sua colega diretora formou-se em sua ideia uma imagem de como seria o novo aluno. Segundo esta imagem seria de um homem negro, grande. Enorme fisicamente. $\mathrm{O}$ corpo cheio de tatuagens que poderiam ser vistas nos braços musculosos que apareciam facilmente já que usava uma "camiseta de física" sem mangas. Confidenciou-nos que passou o resto da noite, e o dia seguinte, muito incomodada com o que lhe esperava - literalmente "em cólicas", como se diz na gíria.

Qual não foi sua surpresa quando, no dia seguinte, ao chegar à escola, encontra the esperando na porta de sua sala um rapaz loiro e de aparência frágil. Vestia uma camisa tipo "polo" azul, cuidadosamente "ajeitada" para dentro da calça bege que usava. Calçava um par de sapatos pretos exemplarmente lustrados. O cabelo estava cortado curto e muito bem penteado. A barba parecia ter sido feita especialmente para a ocasião. Enquanto ela abria a porta da sala o rapaz pediu-Ihe licença, deu boa noite e se apresentou: era o "presidiário bandido" em regime aberto se apresentando para seu primeiro dia de aula na nova escola.

O rapaz contou, então, que em função do novo emprego que havia conseguido, fora transferido para aquela escola já que esta ficava mais perto do trabalho atual. A professora, que teve neste momento uma grande experiência sobre o que é o preconceito, disse: "quase tive um treco". Ela contou-nos que ficou realmente impressionada com a rapidez e naturalidade com que tinha formado uma representação psicológica e física sobre como seria o futuro aluno mesmo sem nunca tê-lo visto. Nem sequer sua voz tinha ouvido. A colega professora confidenciou-nos que essa foi uma das mais marcantes aprendizagens sobre o preconceito e a discriminação que teve oportunidade de viver.

Sem dúvida alguma que não está em jogo aqui - pelo menos de nossa parte - fazer qualquer tipo de julgamento sobre a atitude da professora. Acreditamos que a grande contribuição deste 
depoimento é, justamente, o fato de podermos refletir sobre ele. Um relato da maior importância, principalmente, pelo fato do mesmo ser feito de forma voluntária e generosa pela professora. Ao mesmo tempo em que a professora falava podíamos sentir o quanto ela mesma tinha ficado chocada com a sua atitude. O quanto estava surpresa com a facilidade com que associou "bandido", "presidiário", com a cor da pele da pessoa só para ficar com um dos preconceitos mais frequentes em nossa sociedade. Não se trata de ficarmos imaginado que nós, professores e professoras, tenhamos que ser seres perfeitos ou que não tenhamos contradições e/ou fragilidades pedagógicas e de formação como pessoa. Ao contrário disso, há que aceitarmos que somos seres humanos e, como tal, podemos cometer equívocos e erros. O grande desafio é saber perceber esses equívocos e buscar refletir sobre os mesmos. Sincera, honesta e generosamente.

A narrativa da colega professora, acreditamos, nos dá um excelente exemplo disto. Encaixa-se, muito bem, no que sempre defendeu Paulo Freire, quando dizia que o trabalho com os adultos exige, além de tudo, o que é necessário no trabalho docente nos ciclos regulares, uma atenção amorosa particular, pois, segundo ele, esses educandos(as), são pessoas que, via de regra trabalham o dia todo, têm que se preocupar com a educação dos filhos e, agora, que voltaram a escola, tem que se preocupar, também, com a sua própria escolarização. Isto não é pouca coisa. Imagine-se um alto executivo, um professor de universidade, um professor do ensino básico, um empresário, ter de voltar aos "bancos escolares", ter de assistir aulas diariamente, fazer avaliações periódicas, temas de casa, etc, etc.

Quantos de nós nos submeteríamos a isto? Sinceramente, acreditamos que não. E você colega professor (a) ou leitor (a)?

Quem de nós teria forças para, mesmo em situação de privação de liberdade, começar um longo percurso de escolarização?

Deixamos demais questionamentos e reflexões a critério de cada leitor e leitora e passamos para outra narrativa que consideramos, também, muito desafiadora a todos e todas nós que trabalhamos com a Educação de Jovens e Adultos.

Passamos a seguir a um diálogo que foi oferecido (autor) por uma colega professora que atuava na Educação de Jovens e Adultos, ciclo de alfabetização, em uma sala de aula em um prédio anexo a uma instituição prisional. Vamos ao inusitado diálogo:

Acontecia o primeiro dia de aula. Um estudante recém-chegado ao prédio - anexo ao presídio já um pouco atrasado para o primeiro período, encontra no corredor de entrada uma professora e pergunta:

- Professora sou o aluno apenado da alfabetização noturna que começa a estudar hoje... Onde fica minha sala de aula?

A professora devolve a pergunta com outra: 
- Que série você está cursando meu rapaz?

- Eu sou da turma dos que não sabem nada... Sou da turma dos burros...

- Aaaaaaa... Então, sua sala é lá final do corredor, a última porta virando à direita... se apresse..

- Muito obrigado professora - disse o jovem.

O rapaz saiu apressado, como tinha chegado, e faceiro por ter achado rápido a sala onde estudavam os que não sabiam NADA... Os BURROS (!).

A professora seguiu tranquila seu caminho até desaparecer no final do corredor...

Ela sabia para onde ir.

Afinal, fazia parte da turma dos que sabiam... TUDO (?).

Impossível não lembrar, após este diálogo, do alerta feito por Brandão nos idos da década de 80 quando dizia que uma das grandes contribuições da alternativa de alfabetização proposta por Paulo Freire era nos fazer entender que,

\begin{abstract}
A educação deve ser um ato coletivo, solidário - um ato de amor, dá para pensar sem susto -, não pode ser imposta. Porque educar é uma tarefa de trocas entre pessoas e se não pode ser nunca feita por um sujeito isolado (até a autoeducação é um diálogo à distância), não pode ser também o resultado do despejo de quem supõe que possui todo o saber, sobre aquele que, do outro lado, foi obrigado a pensar que não possui nenhum. (BRANDÃO, 1988, p. 22).
\end{abstract}

Consideramos importante ressaltarmos que, ao trazer para o texto essas narrativas de colegas professores (as) e de educandos e educandas de Educação de Jovens e Adultos, não nos colocamos na posição de juízes ou de críticos especializados, nem como um pesquisadores distantes. Ao contrário, nos colocamos na posição de corresponsáveis pelo que acontece, pois somos, também, mais um profissional da educação.

Vale ressaltar que o Brasil é o terceiro país no mundo ocidental em número de pessoas encarceradas. De outra forma, também não podemos nos furtar de refletir sobre as condições das instituições prisionais, para onde são mandadas as pessoas que pertencem às classes menos favorecidas economicamente nesse país. Segundo o Relatórios do Levantamento Nacional de Informações Penitenciárias (Infopen), do Ministério da Justiça, referentes aos anos de 2015 (dezembro) e 2016 (até junho), mostram que continuam em disparada no Brasil o número total de pessoas presas, a taxa de encarceramento por habitante e o déficit de vagas no sistema prisional. A população carcerária chegou a 726 mil e se tornou a terceira maior do mundo, ultrapassando a da Rússia, que é de pouco mais de 607 mil. Neste ano, o Brasil ficou atrás de Estados Unidos, que tem mais de 2 milhões de presos, e China, com mais de 1 milhão e 600 mil pessoas encarceradas. $O$ número de vagas, por sua vez, está estagnado e alcança apenas a metade. Para cada vaga individual, há duas 
pessoas detidas.Em junho de 2016, eram 726.712 mil presos, sendo 689.510 no sistema penitenciário dos Estados, 36.765 nas Secretarias de segurança/Carceragens de delegacias e 437 no sistema penitenciário federal. O Infopen é realizado pelo Departamento Penitenciário Nacional (Depen).

Passamos agora para a última narrativa e nos encaminhamo-nos para as considerações finais desse texto.

Em um curso de formação de professores (as) de Educação de Jovens Adultos, (Relato do autor) após o trabalho expositivo de uma manhã "reiniciei os trabalhos do período da tarde solicitando que as professoras participantes (só havia mulheres neste curso) falassem um pouco de suas experiências com a Educação de Jovens Adultos já que ali todas eram atuantes nesta modalidade". Algumas, inclusive, já com larga experiência. Qual não foi minha surpresa quando, após um longo silêncio (que em geral é normal nestas ocasiões), várias professoras disseram que não tinham nada para relatar. Que não tinham nada de importante para apresentar para as colegas presentes. Após insistir um pouco mais e perceber que elas não iriam mesmo falar de suas experiências tomei a iniciativa e pedi para que uma delas lesse o seguinte depoimento de uma aluna da Educação de Jovens Adultos, uma mulher negra de 46 anos de idade e que estava participando de um projeto de alfabetização de pessoas em privação de liberdade, que desenvolvi em uma escola estadual em convênio com a vara de execuções criminais de um dado município. Participavam somente mulheres que tinham conseguido benefício de progressão da pena de Regime Fechado para Regime especial semiaberto. Saíam da escola para trabalhar e estudar à noite, retornando para dormir na instituição prisional. Vamos à narrativa da educanda:

"Tentei voltar a estudar por três vezes... na primeira fiz a minha matrícula com a assistente social da cadeia e nem fui até a escola... fiz só pra ganhar uma saidinha da cela...na segunda ocasião me matriculei e tudo..fui até o portão do colégio dei umas volta...uns bordes na redondeza e no horário que terminam as aula voltei pro presídio...na terceira vez entrei até dentro do colégio...até andei pelos corredor...fui nos banheiros...eram bem limpinhos e até cheirosos....bem diferente da cadeia...quando tocou uma sineta saí correndo porta a fora e ganhei a rua...na quarta tentativa em que me matriculei repeti tudo o que tinha feito nas outras vez e fui mais longe...achei a sala de aula onde eu deveria estudar e entrei...levei um baita susto...a professora tinha chegado mais cedo...a danada...e já estava lá dentro....arrumando umas coisas...e eu como sou muito envergonhada não tive coragem de voltar pra trás e fiquei sentada lá no fundo daquela sala...as minhas pernas tremiam...não via a hora da infame da sineta tocar de novo e eu me mandar dali...a professora conversou com todos nós...era uma mulher normal...assim até que nem eu...tinha filhos...era casada...fui ficando...voltei 
no outro dia...no outro...e estou aqui até hoje...ninguém mais me tira da escola...ainda mais que já sei até ler...a assistente social está tentando que eu tenha um indulto de Natal por bom comportamento e aí sim...vai ser muita felicidade..."

Como muito frequentemente ocorre após este depoimento ser lido, a emotividade vêm à tona com muita força. Logo após os primeiros comentários, sobre a fala da aluna, várias professoras participantes começaram a relatar situações semelhantes a esta vivenciada, por elas, em suas respectivas escolas. À medida que cada uma ia falando de suas experiências as outras começavam também a falar das suas.

Passados não mais de uns dez minutos estavam todas falando ao mesmo tempo e querendo contar, uma mais apressada que a outra, as suas histórias sobre a Educação de Jovens Adultos. Solicitei então que nos organizássemos para que falasse uma de uma vez para que todos (as) nós pudéssemos refletir sobre os ricos relatos e experiências descritas.

A partir de então pude mostrar a elas, concretamente, o quanto eram ricas suas experiências e que o que acontecia em uma escola, município ou estado em muitos casos não diferia muito de outros. Ao mesmo tempo, eram experiências pessoais e que carregavam consigo suas especificidades e subjetividades. Tínhamos à tarde para trabalhar e acabamos ficando até o início da noite debatendo e trocando ideias sobre as experiências vividas pelo grupo.

Outra importante contribuição tirada pelo grupo foi à reafirmação da importância de darmos atenção para àquilo que fazemos em nossa prática cotidiana nos espaços educativos, tanto escolares como não escolares. Não foi difícil para o grupo perceber o papel importantíssimo da auto formação aliado à troca de experiência entre colegas. Esse momento de troca é uma excelente oportunidade para fazermos da vivência individual, de um fato vivido no cotidiano, um ponto de partida para a troca de experiências em busca de um fazer coletivo e cooperativo.

\section{ALGUMAS ÚLTIMAS REFLEXÕES}

Começamos a última fase desse texto parafraseando o educador Paulo Freire, quando ele se perguntava: quais seriam os saberes necessários para o (a) educador (a) de Jovens e Adultos? Acrescentaríamos: para além dos saberes necessários para os (as) educadores (as) de Jovens e Adultos em geral, que outros saberes mais ainda seriam necessários para o trabalho educativo, em particular, com adultos em situação de Privação de Liberdade?

A reflexão faz sentido na medida em que frente todas as adversidades enfrentadas por qualquer jovem ou adulto que volta aos bancos escolares, quando tratamos da educação de jovens e adultos em situação de Privação de Liberdade a situação, certamente, merece ser olhada com ainda mais atenção, cuidado e, fundamentalmente, com um alto grau de generosidade de parte de todos os 
setores e/ou pessoas envolvidas com esse grupo tão particular de educando e educandas. Não podemos esquecer-nos que, nesse caso, estamos lidando com pessoas que, pelos mais diferentes desígnios e trajetórias de vida se encontram em situação de encarceramento.

Também, não julgamos ser excessivo lembrar que vivemos em um país que tem a segunda maior população carcerária do mundo ocidental. Aliado a esse cenário dramático, as condições das instituições prisionais brasileiras, com raríssimas exceções, não apresentam as condições mínimas de salubridade e de qualidade de vida para os seus apenados. Como então cumprir um dos preceitos básicos da orientação para a oferta de educação para jovens e adultos em situação de privação de liberdade nos estabelecimentos penais, propostas pelas Diretrizes Curriculares Nacionais para a Educação Básica; Diversidade e Inclusão?

Certamente, que não temos a pretensão de responder, de forma definitiva, a esta pergunta, e muito menos em uma única produção textual. De outra forma, muitas indagações e reflexões poderão ser suscitadas a partir de cada leitor e de sua respectiva leitura. No entanto, esperamos ter, ao longo deste texto, deixado explícitos alguns destes saberes, algumas pistas e trilhas a serem seguidas e/ou (re) inventadas neste caminho ainda por fazer.

Um caminho que nos leve ao cumprimento desta que foi uma das tantas promessas não cumpridas pela modernidade iluminista ocidental: a promessa de escola pública e de uma educação de qualidade para todos e os cidadãos.

Por outro lado, se não dissemos o que fazer, acreditamos ter, em vários momentos, sinalizado algumas das tantas representações e atitudes que não é bom que continuemos repetindo em nossas práticas educativas.

Como não se cansava de repetir Paulo Freire, assustam mais àqueles e aquelas educadoras que estão cheios de verdades e conviç̧ões do que aqueles (as) que estão carregados de dúvidas.

Se a realidade das instituições prisionais brasileiras é mais uma das tantas vergonhas nacionais, ainda, nos resta à esperança (do verbo esperançar) freireana de que as realidades que vivemos não são simplesmente assim. Elas, essas realidades, estão assim. Há que buscar transformálas com solidariedade, cooperação e amor.

Solidariedade, cooperação e amor duas atitudes generosas lembradas pelo presidente da Tanzânia Sr. Julius Kambarage Nyerere, na sua conferência de abertura da Conferência Internacional de Educação de Jovens e Adultos (1996) que se realizou em seu país. Para o presidente da Tanzânia, anfitrião do encontro, "Hacer las cosas significa cooperar con otros". Dando continuidade a sua recepção aos congressistas o presidente afirma, enfaticamente, que "Solo el hombre libre puede desarollarse".

Acreditamos que o que pensa o Senhor Presidente da Tanzânia, para o desenvolvimento de seu povo pode, muito bem, ser transportado para a educação em geral e, para o caso especial para a 
Educação de Jovens e Adultos em situação de Privação de Liberdade, nas instituições prisionais brasileiras.

Para dar uma pausa neste texto queremos reafirmar que quando nos dispomos a pensar a Educação de Jovens e Adultos em geral e, em especial, para jovens e adultos em situação de Privação de Liberdade, não podemos esquecer-nos de levar em conta o longo processo de silenciamento cultural pelo qual passaram boa parte daqueles e daquelas que hoje, em idade adulta, tentam retomar seu processo de educar-se. Desconhecer e/ou desconsiderar estes silenciamentos históricos trata-se de um grave equívoco político na educação, seguido de uma preocupante incompreensão pedagógica.

\section{REFERÊNCIAS}

BRANDÃO, C.R. O que é Método Paulo Freire? São Paulo: Brasiliense, 1988.

A Educação como Cultura. Campinas: Mercado das Letras, 2002.

3. BRASIL. Diretrizes Curriculares Nacionais para a Educação Básica: diversidade e inclusão. Conselho Nacional de Educação : Ministério da Educação, Secretaria de Educação Continuada, Alfabetização, Diversidade e Inclusão, 2013. 480 p.

4. CANDIDO, A. Literatura e Subdesenvolvimento: argumento. São Paulo: PAZ e TERRA, Ano 1, n. 1: 6-24, Out. 1973.

CARREIRA, D. Relatório nacional para o direito humano à educação: educação nas prisões brasileiras. São Paulo: Plataforma DhESCA Brasil, 2009.

FREIRE, P. Pedagogia da Autonomia: saberes necessários à pratica docente. Rio de Janeiro. Paz e Terra, 1997. . Pedagogia do Oprimido. Rio de Janeiro: PAZ e TERRA, 1970. UNESP, 2000. 


\section{Sandra Maders}

Doutora e Mestre em Educação/PPGE/UFSM. Pedagoga.

\section{Valdo Barcelos}

Prof. TITULAR - UFSM. PhD em Antropofagia Cultural Brasileira. Pesq. Prod. 1 - CNPQ. Membro da Academia Internacional de Artes, Letras e Ciências - ALPHAS - 21 - Cadeira Paulo Freire. Membro da Academia Santa Mariense de Letras-ASL - Cadeira Cyro Martins. Consultor MEC/UNESCO MEC/MMA - CYTED - INPA - MCT. 


\section{Como citar este documento:}

MADERS, Sandra; BARCELOS, Valdo. Educação de Jovens e Adultos em privação de liberdade escutando vozes silenciadas. Reflexão e Ação, Santa Cruz do Sul, v. 27, n. 2, abr. 2019. ISSN 19829949. Disponível em: <https://online.unisc.br/seer/index.php/reflex/article/view/12542>. Acesso em: doi:https://doi.org/10.17058/rea.v27i2.12542. 